УДК 616.69-008.14+616.89-008.442]-085.851

\title{
COGNITIVE TECHNIQUES IN CLINICAL SEXOLOGY
}

Kocharyan G. S.

Наведено різні когнітивні прийоми для лікування хворих із сексуальними дисфункціями. Майже всі вони розроблені автором статті.

Ключові слова: сексуальні дисфункції, психотерапія, когнітивні прийоми.

Different cognitive techniques for the treatment of patients with sexual dysfunctions are presented. Almost all of them were developed by the author of the article.

Keywords: sexual dysfunction, psychotherapy, cognitive techniques.

Представлены различные когнитивные приемы для лечения больных с сексуальными дисфункциями. Почти все они разработаны автором статьи.

Ключевые слова: сексуальные дисфункции, психотерапия, когнитивные приемы.

Sexual disorders are significant for the personality, especially for males. For this reason sexual dysfunctions can result in various negative consequences, including neurotic disorders. There are a number of methods aimed to adapt the personality to the existing sexual disorders and correct the scale of feelings.

The method of "somatization" [1] is used for treating true nonpsychogenic sexual disorders. It is recommended (avoiding iatrogenias) to explain the patient that a sexual disorder is the same equivalent sign of a somatic disease as others (headache, insomnia, breathlessness, oedemata, higher arterial pressure, etc.). He should be informed that sexual disorders will decrease and disappear like other somatic signs do.

Often sexual disorders are not combined with any pronounced nonsexual manifestations of somatic diseases. As the result the method of "somatization" cannot be used. For such cases, when erection is reduced and personality reactions are pronounced, we suggested the method of decreasing the rank of significance of sexual disorders [2]. Its essence is as follows. At first the patient is explained the physiological mechanism of erection development, including the information that the appearance of tension in the penis is caused by blood supply to this organ. Then the patient is gradually driven to the thought that he groundlessly reduces to a large extent the purport of life to blood supply of his penis. When the patient is convinced that this is how matters stand, he develops confusion and bewilderment. The achieved result is the starting point for further reexamination of his situation that naturally leads to reduced fixation on the sexual disorder and a better mood. Simultaneously, emphasis is made on other interests of the personality and their actualization is performed. All these measures create favourable conditions for combined treatment of the sexual disorder, including use of other psychotherapeutic methods too.

The method of "comparison by contrast" [3] can be used in combined treatment of patients with phobic forms of virgogamy and vaginism (classification by A.M. Sviadoshch [9]). It is recommended to carry on the conversation in the following way. At first it is necessary to tell the female patient about great capabilities of the vagina to enlarge and confirm it by giving

(C) Кочярян Г. С., 2016 
an example of childbirth. One should point to the fact that the body weight of the normal baby and its growth at birth reach large values (inform about their ranges). Then it is reasonable to mention that the length and volume of the male penis are immeasurably smaller. Thereby the woman is vividly shown the contrast between the size of the foetus and penis. This factor creates favourable conditions for carrying out more successfully other therapeutic (mainly psychotherapeutic) measures aimed to eliminate the existing pathology, because it contributes to reduction of the degree of manifestation of the phobic potential as the result of its discredit.

In some cases (higher anxiety, increased suspiciousness) the patient believes that his defect (rather often imaginary or only feebly marked) is known for both his female partner and other people, since his sexual disorder manifests itself with something in the man's behaviour and leaves an impression of sexual defect on his whole appearance rather than it is evident only during intimacy. This fact significantly affects his state of mind and is the origin of bad feelings, which depress the patient. Having made sure on examination that this is how matters stand, the physician should resort to "psychotherapy with regard for the mechanism of projection" [3]. Its essence is as follows. It is necessary to explain the patient that his feelings result from ascription of his own thoughts and knowledge to people around him. It should be pointed out that in reality his woman may not even have any idea about his imaginary defect (or slight disorder). Besides it is necessary (taking into regard concrete circumstances) to explain the patient that in a number of cases the female partner may not suspect even the presence of rather pronounced sexual disorders because of primary orientation of some women to erotic influences (caresses, kisses) with an opportunity to receive satisfaction during intimacy without orgasm as well as due to rather common lack of information about the sexual norm. Such a course of correction of hypernosognosia manifestations can give appreciable results, creating the atmosphere of "security".

The method of "comparison by analogy" [6]. The sexual sphere is highly vulnerable, since as a result of the sexual function twoness this is included into the context of interpersonal relations. Therefore any imaginary and true sexual disorders can strike powerful blows to the personality prestige, forming in the male the feeling of his inferiority. It is natural that in a number of cases sexual problems are suffered with particular acuteness; for example, in the presence of anxious- hypochondriac character traits. Such patients may attribute their sexual deficiency to a "small" size of their penis ("small penis syndrome") and sometimes that of their testes. Thus, for example, one of our patients with sensitive accentuation of character and anxious sexual failure expectation syndrome complained of a small size of his penis, whose measurement values turned out to be larger of the lower norm limits, as well as some decrease of one of his testes, while its examination did not reveal any difference from the other one. Analysing such cases we have drawn the conclusion that such disturbed perception can be assessed by analogy to an optic distortion, which occurs when an object is examined through a lens at a short distance (a biconvex lens, when the object is placed at a distance less than focal). But the observations, which we characterize, deal with distortions of the psychic nature caused by a hypertrophied assessment of the events, which take place. This whole situation reminds a caricature, when an artist exaggerates some facial characteristics, which express features of the person's character. It should be noted that an inclination for grotesque is laid in the very psyche of the human being and caused by his/her more or less emotional, rather than neutral, perception of any significant things. It is this fact that is the source for distortion of the perceived. 
The sixth exercise of the highest stage of autogenic training (autogenic meditation), developed by Schultz, can serve as an illustration. When doing this exercise the trainee should learn to visualize other people. At first it is recommended to concentrate his/her attention on comparatively indifferent images (postmen, bus drivers, etc.), since at the first stages any visualization of the persons, who have some relations (both positive and negative) with the trainees, is difficult.

As the person advances in his mastering of the exercise, he learns how to visualize other people who are pleasant and unpleasant for him. Initially these images are somewhat caricatured, since their pleasant or unpleasant features are subconsciously hyperbolized and only with time become more and more "calm", "passionless", without any elements of emotional hyperbolization. This is regarded as an important index of success in mastering of the exercise, a manifestation of the beginning of "autogenic neutralization".

During psychotherapy in the cases, described by us, we should strive for "neutralization" too. In our opinion, this correction should operate with accessible and obvious analogies, like the above one from optics. Having drawn this analogy we tell the patient that if the person understands peculiarities in his/her character, which like a magnifying glass refract the events that take place, then this person becomes stronger because of the possibility to carry out autocorrection. In our talk with this patient we point out that "existence should be raised to the height of consciousness" and mention words of a famous thinker, who said that he would give up knowledge without an ability to display it.

In any psychologically stressful situation we recommend the patient to recall that he perceives the events, which take place, in another way, unlike other people and to imagine a distortion of the object, which is examined through a lens. This will help him in assessment of the real significance of the events, which take place. In order to help the patient in this aspect, another analogy is used and this is from optics too. We point out that events can appear with their true significance in that case when a previously magnified image is passed through a biconcave lens, a diminishing glass. It will result in reassessment of the events, which will take place, in accordance with their true significance.

The method of "false signal" [4]. Sometimes sexologists may see patients, who fix their attention on the sensations, which originate in their sex organs and in some cases have the character of senestopathies. Thus, for example, one of our patients with a suspected sluggish schizophrenic process, who revealed certain characterological shifts, complained of periodical appearance of unpleasant sensations and pains in his right testis with their radiation to the right lower quadrant of the abdomen and the inner surface of his right thigh. Describing the character of sensations in his testis, he noted that "at first the sensation of blockage appears, and then as if something burst out and circulation begins". Fixation of attention on senestopathic sensations, which are localized in the region of sex organs and accompanied with apprehension for the state of one's health (senestopathic-hypochondrial syndrome), causes indirect decrease of libido, since the patient is usually concerned about his state and also quite often is not sure of his sexual capacities. In these cases the following argumentation can help in psychotherapeutic explanatory work.

We usually begin our talk with fixation of the patient's attention on results of his objective examinations, which have not revealed any pathology in his sex organs. Then we point out that those impulses, which originate from one's intact organs, usually are not perceived by the person. 
But in some cases, as results of dysfunctions in certain formations of the brain, these impulses reach its higher (cortical) parts and are perceived as painful sensations. This results in the situation of a peculiar physiological illusion, when the real state of things does not correspond to their assessment (a "distorting mirror").

In order to make the perception of what is stated more understandable we usually tell the following story. Before one family left their apartment to be on holiday, the apartment was safeguarded with an alarm system. The latter went off twice during the holiday period. But every time it was found out that nobody encroached upon the owners' property. Therefore, we conclude that everything at the apartment was absolutely all right, and it was necessary to look for defects in the system, which provided the alarm. Also effective can be the following auxiliary method, which we use. The patient is told that quite often those people, who have lost their extremity (an arm or a leg), feel some pain in it. During our talk we usually point out that when a person fixes his/her attention on any organ or part of one's body, he/she is sure to feel them. In order to confirm this idea the following question is asked, "Tell me, please, did you feel your left thumb before I asked you about it?" The patient always answers that he did not. In this way we stimulate him of his own free will not "to lend his ear" to such painful sensations.

The effect on the patient can be also increased by means of a popular description of data about "somatization" of realized concentration. Thus, it is known that though concentration is by its nature a psychic process, but during its realization it is instantly "somatized" [8]. Attention, intently fixed on any part of the body, interferes with contraction of small arteries in it. Therefore vessels in this place weaken and are immediately filled with arterial blood. It has been shown that concentration on receptive fields (tactile, temperature, proprioceptive and other sensitivities) is accompanied with an increase of their sensitivity (lowering of the threshold). An experiment of using autogenic training with objective registration of skin temperature and carrying out of plethysmography showed that dilation of extremity vessels developed in the majority of subjects without use of proper autosuggestion formulae, but simply because they were suggested to keep their concentration on the extremity during 3-5 minutes. Even concentration on strictly limited areas of their trunk, arms and legs resulted in decreased intensity of skin tension (data of tensometry), enlargement of this body part (data of plethysmography), decreased bioelectrical activity of the adjacent muscle layer and elevation of skin temperature by $1.5-3^{\circ} \mathrm{C}$.

The cited data [8] reveal the pathogenic role that can be played by forced (passive) concentration, which is caused by pathological hypochondria and directed, in particular, at the function of analyzers. Despite the whole severity of senestopathic sensations, which are localized in the region of sex organs, the above psychotherapeutic "treatment" can slightly improve the subjective state of the patients, if these sensations are not related to delirious feelings.

The method of "extension of consciousness" [5]. Starting treatment of a patient with a sexual disorder, the physician always regards this disorder as evil, therewith supporting the patient's confidence in it that already exists. But in such cases the concrete context of partner relationships is not always taken into account. Thus, for example, we are strongly convinced of the fact that in some cases the above disorder can have a positive value, acting as an indicator of reliability of the partner communication. Really, when during the partnership that is predicted to turn into an alliance the man develops some sexual failure, in some cases the woman demonstrates her irreconcilability to this disorder with a subsequent break of relations. 
As the result, the man's anxiety caused by the sexual failure is supplemented with feelings associated with his fear to lose the beloved person.

To our mind, it is reasonable in such cases to orientate the patient to assess his sexual disorder from another, alternative position. We inform the patient that his understanding of the present situation is narrow and that his disorder in this particular case is his benefit rather than evil. It is very good that the disorder has appeared just now and not later so that he has been able at the proper time to get to know the person with whom he wanted to cast his lot. In reality it has turned out that they did not have anything common between them, but bed. Thereby, we conclude, the sexual disorder has played a positive role. It is also useful in such cases to ask the patient to imagine what would happen if this disorder developed much later, when many years after their marriage they would have common children, joint accommodation and household and he would be bound with his wife by many other social relations.

The following parable, which is useful to be told to the patient, can also help to convince him of his limited assessment of what has happened, because this assessment does not take into account the whole "fullness" of understanding of the problem. An old Chinese man was the only person in his village, who had a horse. Naturally, he was richer than the others, because he was able to plough more land. Everybody considered him happy, until his horse ran away. Then they began to feel sorry for him. A few days later his horse came back and brought a wild horse with it. Since now the second horse belonged to him too, everybody began to say about his luck. But next day, when his son tried to climb the wild horse, he fell down and broke his leg. Fellow villagers thought it to be a misfortune. Some time later the village was attended by messengers of the emperor, who took young men to the army. It is clear that the son of the old Chinese man was not taken to the army because of his broken leg. This parable in the allegorical form helps to look at the events, which take place, in a different way. It turns out that some disorder (the "broken leg") may definitely fulfil a positive function. Naturally, such an access does not mean cancellation of eradication of sexual disorders.

The above psychotherapeutic method, which we have described, is aimed at reconsideration of his situation by the patient, results in decrease of psychic tension and proved to be very effective during its clinical testing.

To our mine, the literature reflects rather disputable recommendations of A. Finkel, $\mathrm{R}$. Thompson [10] concerning the information that is advised to give patients in connection with the psychogenic sexual dysfunction, which they have. Thus, the physician declares them that they suffer from "moderate prostatitis". As the above authors believe, this diagnosis produces a less severe psychological effect on the patients versus those cases when the patients regard their erectile disturbances as purely psychogenic. The patients were prescribed to increase the volume of liquid, which they took, as well as they were administered a sulfanilamide medicine. During their subsequent visits they were assured that prostatitis was gradually cured. Some time later they were told that they could try to resume their sexual intercourses at favourable opportunities. The authors inform that $60 \%$ of those 84 males, who underwent the above course of treatment, developed a sufficient degree of improvement.

Essentially, such a "psychotherapeutic" influence is an artificial method of "somatization", whose use can produce a iatrogenic effect, since there is a common opinion about incurability 
of prostatitis, especially if its manifestation is moderate. To our mind, the diagnosis of a psychogenic disorder of potency, caused by psychological factors, seems much more harmless.

We also use special cognitive methods for correcting the internal picture of disease in those patients, who are concerned about duration of their coitus [7]. These methods are based on explanation of causes of development of ejaculatory disorders and are aimed to change the patients' attitude to them. It is far from being always that changes in the duration of coitus are manifestations of pathology. Thus, for example, premature ejaculation can often result from long breaks in a sex life. In such cases it is reasonable to explain the patient the relationship between the duration of coitus and frequency of sexual contacts. We usually draw an analogy between the present situation and the situation with a hungry person: we ask the man to answer the question, whether he would eat fast if he were not fed during several days. This method is rather effective. If the coitus passes fast, it is also necessary to carry out work for strengthening the patient's self-respect by drawing an analogy with other behavioural acts, whose rapid fulfillment demonstrates high competence and good capacities of the person [7]. Thus, for example, if some specialist rapidly carries out a task, assigned by his leader, this is a positive characteristic for this worker. In this vein it is possible to make a comparison with a rapid solution of mathematical problems. The male's self-appraisal can be also raised by telling him that patients with hypogonadism (persons, whose production of the male sex hormone is decreased for different reasons) are characterized by low sex reactivity. The latter is based on a sharp weakening of libido that, in particular, can manifest itself by very prolonged coituses, which sometimes may not end with ejaculation. It is also possible to give examples with elderly people, in whom not every sexual intercourse ends with ejaculation because of influence of factors, caused by aging [7].

Measures aimed to raise self-appraisal of people with an increased duration of coituses have their own peculiarities. One male, who took our medical advice, complained of a very long duration of each sexual intercourse and, what is more, he could finish it only having intensified frictions and got ready for the end. We informed the patient that very often we came across cases with premature ejaculation and so he, the man who was able to carry out prolonged coituses and finish them of his own free will, should be proud of it. In the process of this work the patient's selfappraisal considerably improved. But this did not exclude the necessity of pharmaceutical therapy aimed to reduce the duration of sexual intercourses. In cases of anejaculation with unaffected erection it is possible to attract the male's attention to the existing positive thing. Thus, for example, we told one of our patients, who stated that he "could not come", that it was much better than if he "could not start" (meaning an erectile disorder) and much better than premature ejaculation, because he was able to satisfy any woman. The talk, carried out in such a vein, produced a pronounced positive effect on him, though not in the least it cancelled the necessity of biologically oriented therapy [7].

In connection with what was stated above it is necessary to remind that the same phenomenon can be perceived in different ways. It is the point of view that much depends upon. In this respect, the following funny story is interesting. We mean a man, who was treated by a psychologist for night enuresis and remained very satisfied with it. When he was asked whether he got rid of that disorder, the answer was negative. But this person stated that he began to respect himself because of its presence. 
It goes without saying that the cognitive methods, which were described above, do not cancel the necessity of eradication of ejaculatory disorders, especially in patients with pathology, where these disorders distort or embroider the real situation. But in our case the above methods fulfil a positive psychoprotective function [7].

\section{References}

1. Dvorkin E. M. Psihoterapiya seksualnyih rasstroystv: Rukovodstvo po psihoterapii / Pod red. V. E. Rozhnova. - 2-e izd. - Tashkent, 1979. - S. 420-434.

2. Kocharyan G. S. Psihoterapevticheskiy podhod pri nekotoryih seksualnyih rasstroystvah s gipoerektsiey // Mediko-psihologicheskie aspektyi braka i semi: Tez. dokl. obl. nauch.-prakt. konf. seksopatologov. - Harkov, 1985. - S. 134.

3. Kocharyan G. S. Priemyi ratsionalnoy psihoterapii v seksologicheskoy praktike // Sotsialno-psihologicheskie i meditsinskie aspektyi braka i semi: Tez. dokl. 3-y obl. nauch.-prakt. konf. seksopatologov. - Harkov, 1987. - S. 422-423.

4. Kocharyan G. S. Senestopatii v klinike seksualnyih rasstroystv i vozmozhnosti ratsionalnoy psihoterapii // Nemedikamentoznyie metodyi kupirovaniya bolevyih sindromov: Tez. Resp. nauch. konf. - K., 1989. - S. 177-179.

5. Kocharyan G. S. Priem «rasshireniya soznaniya» v korrektsii masshtaba perezhivaniy patsientov s seksualnyimi narusheniyami // Aktualnyie aspektyi diagnostiki, organizatsii lechebnogo protsessa i reabilitatsii bolnyih s seksualnyimi rasstroystvami: Tez. dokl. 4-y obl. nauch.-prakt. konf. seksopatologov. - Harkov, 1990. - S. 215-217.

6. Kocharyan G. S. Priem «sopostavlenie po analogii» v seksologicheskoy praktike // Aktualnyie aspektyi diagnostiki, organizatsii lechebnogo protsessa i reabilitatsii bolnyih $\mathrm{s}$ seksualnyimi rasstroystvami: Tez. dokl. 4-y obl. nauch.-prakt. konf. seksopatologov. - Harkov, 1990. - S. 213-215.

7. Kocharyan G. S. Rasstroystva eyakulyatsii i ih lechenie. - H.: Vid-vo VIrovets A. P. «Apostrof», 2012. - $328 \mathrm{~s}$.

8. Mirovskiy K. I. Sosredotochenie i ego rol v realizatsii psihoterapevticheskogo samovozdeystviya // Voprosyi meditsinskoy deontologii i psihoterapii. - Tambov, 1974. - S. 6164.

9. Svyadosch A. M. Zhenskaya seksopatologiya. - M.: Meditsina, 1974. - 184 s.

10. Finkel A., Thompson R. Alternatives to androgenic hormones in treating male impotency // Geriatrics. - 1972. - Vol. 27. - P. 74-76. 